\title{
Evaluation of the Haematology and Biochemistry of Clarias gariepinus as Biomakers of Environmental Pollution in Tiga dam, Nigeria
}

\author{
Samson Eneojo Abalaka* \\ Department of Veterinary Pathology, Ahmadu Bello University, Zaria, Nigeria
}

\begin{abstract}
This study aimed to evaluate the haematological and biochemical changes in Clarias gariepinus as biomarkers of environmental pollution in Tiga dam, Nigeria (wild aquatic environment). Water and fishes were sampled twice, a week apart, from the controlled and the wild aquatic environment. There were no significant $(p>0.05)$ differences between the temperature, $\mathrm{pH}$ and dissolved oxygen contents of both aquatic environments. Similarly, there were no significant $(p>0.05)$ changes in the haematological parameters of the reared and wild the $\mathrm{C}$. gariepinus except in their white blood cell counts, which were significantly $(p<0.05)$ higher in wild $\mathrm{C}$. gariepinus. The activities of aspartate aminotransferase, alanine aminotransferase and alkaline phosphatase (serum enzymes) were significantly $(p<0.05)$ higher in the wild $\mathrm{C}$. gariepinus. However, the concentrations of serum total triglyceride (serum metabolite) were significantly $(p<0.05)$ lower in the wild $\mathrm{C}$. gariepinus. The haematological and biochemical alterations in the wild $\mathrm{C}$. gariepinus, which were strongly indicative of cellular damages, might have been a consequence of the toxic pollution of Tiga dam, Nigeria.
\end{abstract}

Key words: Catfish, Serum enzymes, Serum metabolites, Blood values, Aquatic environment

\section{INTRODUCTION}

Clarias gariepinus, which is indigenous from Africa (Rahman et al. 1992), is one of the most important tropical catfish species for aquaculture (de Graaf and Janssen 1996) in spite of its commanding presence in the wild. This might have been due to its high growth rate, omnivorous feeding habit, high feed conversion rates and hardiness, including its high resistance to handling and stress (Olaifa et al. 2003; Eyo and Ezechie 2004; Akinsanya and Otubanjo 2006; Ogundiran et al. 2009). Clarias gariepinus is known to tolerate harsh aquatic conditions (Hogendoorn 1992; Bruton 1979) in terms of low dissolved oxygen concentrations by utilizing both dissolved and atmospheric oxygen (Okechi 2004), especially in fishes above $12-14$ days old with functionally developed accessory respiratory organs (Peteri et al. 1992). Though $C$. gariepinus can endure long periods of draughts (Dunn 2000), it cannot survive long in water temperature below $9-10^{\circ} \mathrm{C}$ (Peteri et al. 1992). These endearing qualities may have increased the importance of $C$. gariepinus in ecotoxicological studies (Weckler 2000).

Clarias gariepinus, like any other aquatic organism, live in direct contact with the aquatic environment where some changes are rapidly reflected as measurable patho-physiological alterations in exposed fishes (Wilson and Taylor 1993; Musa and Omoriegie 1999; Seith and Saxena 2003). However, such measurable changes

*Author for correspondence: rina_ray64@yahoo.co.in 
depend upon the biological status of exposed fish as well as upon the type and duration of their exposure to toxicants within that aquatic environment (Brungs 1977). That is why fishes are used as acceptable bio-indicators of environmental pollution (Nussey et al. 1995; Kock et al. 1996; Borkovic et al. 2008; Kim et al. 2008), especially as most aquatic waters are constantly being threatened by the environmental pollution (Biney, et al. 1987; Svensson et al. 1996; Adamu and Kori-Siakpere 2008). This is because normal physiological processes are long affected before the death of an organism thereby creating the need for physiological and biochemical indicators of health and sub-lethal effects of the toxicants (Van Vuren 1986; Van der Merve et al. 1993).

The increasing spates of water pollution have continued to be a major problem in Nigeria and other developing countries (Adelegan 2008). Ayodele and Abubakar (2001) and Sani (2011) have reported the pollution of Tiga dam, Nigeria. However, there is dearth of information on the effects of such pollution on the haematological and biochemical profile of Tiga dam's fish biota. Thus, this study aimed to evaluate the haematology and biochemistry of $C$. gariepinus as biomarkers of environmental pollution in Tiga dam, Nigeria.

\section{MATERIALS AND METHODS}

\section{Physicochemical Parameters}

Water samples were randomly taken from Tiga dam, Nigeria (wild aquatic environment) and from a concrete pond (controlled aquatic environment) within the early hours of the morning (0800 $0900 \mathrm{~h}$ ). These were immediately stabilized with manganous sulphate prior to analysis within the first three hours of sampling $(0900-1200 \mathrm{~h})$. Water samplings were performed twice, a week apart, in April 2010. Temperature and $\mathrm{pH}$ was determined using Hanna Instrument hand held meter (Hi 98129, PHK-260-010Y) after calibrations. Dissolved oxygen concentrations were determined using the modified WinklerAzide method as described by Lind (1979) and APHA (1985).

\section{Fish Sampling}

Clarias gariepinus $(403.00 \pm 26.44 \mathrm{~g}$ mean weight and $37.30 \pm 0.81 \mathrm{~cm}$ mean total length) were purchased from a commercial fish farm (Fannasson Investments Limited, Rano, Kano
State, Nigeria). Fish were acclimatized for 14 days in a concrete pond prior to sampling. Fishes were fed $6 \mathrm{~mm}$ Coppens ${ }^{\circledR}$ fish feed for aquaculture (Coppens International bv. 5700 AM Helmond, Holland) satiation in two divided portions per day throughout the experimental period. Pond water was changed completely once in every two days. Clarias gariepinus $(340.40 \pm 19.62 \mathrm{~g}$ mean weight and $38.75 \pm 0.99 \mathrm{~cm}$ mean total length) were caught from Tiga dam, Nigeria.

Reared $C$. gariepinus were randomly netted using locally fabricated hand catching nets. Wild $C$. gariepinus were caught by local fishermen using dug-out canoes and dragging nets. Similarly, the reared and wild fishes were sampled twice, a week apart, in April 2010 as earlier performed for the water. Caught fishes were held in plastic containers with fresh concrete pond and fresh Tiga dam water prior to blood sampling within the first three hours of their capture as suggested by Kurtović et al. (2008).

\section{Haematological Analysis}

Blood samples were collected via caudal vein puncture as described by Kori-Siakpere et al. (2005). Fish was held by the person to collect the blood in a slanting and/or vertical position with the ventral part facing the person. Blood samples were collected with sterile $5 \mathrm{ml}$ syringe and $21 \mathrm{G}$ needle. The needle was introduced on the ventral mid line between the anal opening and the beginning of the anal fin to assess the caudal vein beneath the vertebral column. The first portion of the collected blood was dispensed into heparinised tubes for haematological analysis. Red blood cells (RBC) and White blood cells (WBC) counts were estimated using a Neübauer haematocytometer with Hendricks (1952) diluting fluid for RBC counts and Shaw (1930) solution for WBC counts as described by Hesser (1960). Haemoglobin (Hb) concentrations were estimated using the SahliHellige haemoglobin method as described by Hesser (1960). Packed cell volume (PCV) was estimated using a micro-haematocrit method as described by Hesser (1960). Mean corpuscular volume (MCV), mean corpuscular haemoglobin $(\mathrm{MCH})$ and mean corpuscular haemoglobin concentration (MCHC) values were estimated as follows (Stockham and Scott 2002 ):

$$
\operatorname{MCV}(\mathrm{fL})=\frac{\mathrm{PCV}}{\mathrm{REC}} \times 10
$$




$$
\begin{aligned}
& \operatorname{MCH}(\mathrm{pg})=\frac{\mathrm{Hb}}{\mathrm{RBC}} \times 10 \\
& \operatorname{MCHC}(\mathrm{g} / \mathrm{dL})=\frac{\mathrm{Hb}}{\mathrm{PCV}} \times 100
\end{aligned}
$$

\section{Biochemical Analysis}

The second portion of the collected blood was dispensed into non-heparinised tubes. This was then centrifuged at 1,006 $\mathrm{xg}$ for five minutes to obtain the serum. Serum glucose concentrations were estimated based on glucose oxidase method as described by Morgan and Iwana (1997). Serum total triglyceride concentrations were estimated based on enzymatic method as described by Tietz (1990) using a commercially available kit (Randox Laboratory Limited, United Kingdom). Serum total protein concentrations were estimated based on Biuret method as described by Henry et al. (1974) using an auto-analyzer (Bayer Express Plus, Model 15950, Germany). Aspartate aminotransferase (AST) and alanine aminotransferase (ALT) activities were estimated as described in the Reference method by the International Federation of Clinical Chemistry as described by Schwartz et al. (1985) using the same auto-analyzer as above. Alkaline phosphatase concentrations were estimated based on the enzymatic hydrolysis method as described by King and Armstrong (1934).

\section{Statistical Analysis}

GraphPad software programme (GraphPad Prism, version 4, San Diego, CA) was used to analyse the data as means \pm SEM while student's $t$-test were performed to determine differences between the means at $p<0.05$ statistical significance.

\section{RESULTS}

The temperature, $\mathrm{pH}$ and dissolve oxygen of the controlled and wild aquatic environments are as shown in Table 1. Evidently, there were no significant $(p>0.05)$ differences between the temperature, $\mathrm{pH}$ and the dissolved oxygen concentrations of both aquatic environments.

The haematological parameters of the reared and wild $C$. gariepinus are as shown in Table 2. There were no significant $(p>0.05)$ differences between the $\mathrm{Hb}, \mathrm{PCV}, \mathrm{RBC}, \mathrm{MCV}, \mathrm{MCH}$ and $\mathrm{MCHC}$ of the reared and wild C. gariepinus except in their WBC counts, which were significantly $(\mathrm{p}<0.05)$ higher in the wild C. gariepinus.

Table 1 - Physicochemical parameters of the controlled (commercial fish farm) and wild (Tiga dam, Nigeria) aquatic environments.

\begin{tabular}{lccc}
\hline Physicochemical parameters & Controlled aquatic environment & Wild aquatic environment & P-value \\
\hline Temperature $\left({ }^{\circ} \mathrm{C}\right)$ & $25.87 \pm 0.03$ & $25.83 \pm 0.17$ & 0.85 \\
pH & $7.34 \pm 0.04$ & $7.13 \pm 0.06$ & 0.05 \\
DO $(\mathrm{mg} / \mathrm{L})$ & $6.23 \pm 0.50$ & $5.20 \pm 0.07$ & 0.11 \\
\hline
\end{tabular}

Values with asterisk $(*)$ are statistically significant $(\mathrm{p}<0.05)$ within the row

Table 2 - Haematological parameters of the reared (commercial fish farm) and wild (Tiga dam, Nigeria) Clarias gariepinus.

\begin{tabular}{lccc}
\hline \multicolumn{1}{c}{ Haematological parameters } & Reared Clarias gariepinus & Wild Clarias gariepinus & p-value \\
\hline $\mathrm{Hb}(\mathrm{g} / \mathrm{L})$ & $118.00 \pm 8.24$ & $116.70 \pm 7.15$ & 0.9036 \\
$\mathrm{PCV}(\%)$ & $34.07 \pm 2.49$ & $34.53 \pm 2.28$ & 0.8911 \\
$\mathrm{RBC}\left(\mathrm{x} \mathrm{10} 0^{12} / \mathrm{L}\right)$ & $221.30 \pm 17.16$ & $192.30 \pm 13.74$ & 0.1979 \\
$\mathrm{WBC}(\mathrm{x} \mathrm{10} / \mathrm{L})$ & $3.02 \pm 0.28$ & $4.18 \pm 0.28$ & $0.0068^{*}$ \\
$\mathrm{MCV}(\mathrm{fL})$ & $1.89 \pm 0.14$ & $1.64 \pm 0.15$ & 0.2591 \\
$\mathrm{MCH}(\mathrm{pg})$ & $6.42 \pm 0.49$ & $5.79 \pm 0.58$ & 0.4220 \\
$\mathrm{MCHC}(\mathrm{g} / \mathrm{dL})$ & $339.60 \pm 4.17$ & $348.10 \pm 7.37$ & 0.3259 \\
\hline
\end{tabular}

Values with asterisk $(*)$ are statistically significant $(\mathrm{p}<0.05)$ within the row

$\mathrm{Hb}$ - Haemoglobin; PCV - Packed cell volume; RBC - Red blood cells; WBC - White blood cells; MCV - Mean corpuscular volume; $\mathrm{MCH}$ - Mean corpuscular haemoglobin; MCHC - Mean corpuscular haemoglobin concentration

The biochemical parameters of the reared and wild Clarias gariepinus are as shown in Table 3. The activities of serum enzymes (AST, ALT and
ALP) were significantly $(\mathrm{p}<0.05)$ higher in the wild $C$. gariepinus compared to the reared $C$. gariepinus. The concentrations of serum 
triglyceride were significantly $(\mathrm{p}<0.05)$ lower in the wild $C$. gariepinus compared to the reared $C$. gariepinus. However, there were no significant ( $>0.05$ ) differences in the concentrations of the other serum metabolites (serum glucose and serum total protein) between the reared and wild C. gariepinus.

Table 3 - Biochemical parameters of the reared (commercial fish farm) and wild (Tiga dam, Nigeria) Clarias gariepinus.

\begin{tabular}{lccc}
\hline Biochemical parameters & Reared Clarias gariepinus & Wild Clarias gariepinus & p-value \\
\hline AST (U/L) & $155.00 \pm 12.72$ & $463.70 \pm 32.90$ & $<0.0001^{*}$ \\
ALT (U/L) & $49.17 \pm 4.84$ & $237.20 \pm 27.10$ & $<0.0001^{*}$ \\
ALP (U/L) & $24.96 \pm 0.70$ & $27.62 \pm 0.80$ & $<0.01^{*}$ \\
Glucose (mmol/L) & $4.36 \pm 0.27$ & $5.54 \pm 0.56$ & 0.80 \\
Total protein $(\mathrm{g} / \mathrm{L})$ & $32.09 \pm 1.79$ & $30.12 \pm 1.69$ & 0.42 \\
Total triglyceride (mmol/L) & $0.04 \pm 0.00$ & $0.02 \pm 0.00$ & $0.0001^{*}$ \\
\hline
\end{tabular}

Values with asterisk $(*)$ are statistically significant $(\mathrm{p}<0.05)$ within the row

AST - Aspartate aminotransferase; ALT - Alanine aminotransferase; ALP - Alkaline phosphatase

\section{DISCUSSION}

The physicochemical parameters of both aquatic environments were within acceptable levels for the survival of $C$. gariepinus as earlier reported by Viveen et al. (1985) and Peteri et al. (1992), especially as the fish has wide tolerance for temperature ranges, low dissolved oxygen and high salinity (Ozmen et al. 2006). These might have accounted for the insignificant ( $p>0.05)$ changes in the oxygen transport vehicles $(\mathrm{Hb}$, PCV, RBC, MCV, MCH and MCHC) of $C$. gariepinus from both aquatic environments. The method of sampling adopted in this study was to guard against the effect of seasonal fluctuations as suggested by Kurtović et al. (2008).

Significant $(\mathrm{p}<0.05)$ increase in WBC counts in the wild $C$. gariepinus might be a protective response to stress (Das 1998; Dhanekar et al. 1985) as well as a consequence of tissue damages (Choo and Williams 2003; Adeyemo 2007; Masheswaran et al. 2008). Unacceptable concentrations of lead and cobalt have been reported in Tilapia and catfish tissues sampled from Tiga dam, Nigeria by Sani (2011). The fact that heavy metals pollution of aquatic environments are known to cause physiological, biochemical and cellular alterations in the exposed fishes (Martinez et al. 2004; Al-Attar 2005; Adeyemo 2007; Mohamed 2008; Atamanalp et al. 2010) underscores the presence of these cellular damages. Heavy metals pollution of Tiga dam may have been due to the active mining activities on the Jos highlands, which serves as the originating source of Kano River supplying it.
Increased significant $(\mathrm{p}<0.05)$ activities of serum enzymes (AST, ALT and ALP) in the wild $C$. gariepinus also resulted from cellular damage in these fish, which might have arisen from the toxic pollution of the aquatic environment. This is because serum enzymes are cytoplasmic in nature and are only released into blood circulation after cellular damage (Sallie et al. 1991; Palanivelu et al. 2005). Significant $(p<0.05)$ reduction in serum total triglyceride concentrations of the wild $C$. gariepinus compared to the reared $C$. gariepinus might have been due to liver dysfunction (Kaplan et al. 1988) resulting from liver damage caused by the destructive effects of toxicants in the dam.

In conclusion, the effects of the environmental pollution were more pronounced in serum enzymes activities than in the haematological responses of the exposed $C$. gariepinus. However, significant $(p<0.05)$ increase in serum enzymes and WBC counts of the wild $C$. gariepinus were indicative of cellular damages in exposed fishes. Therefore, higher haematological and biochemical values in apparently healthy $C$. gariepinus sampled from Tiga dam, Nigeria might be indicative of toxic pollution of this wild aquatic environment.

\section{ACKNOWLEDGEMENTS}

Author would like to acknowledge the immense contributions of Mr. Abdulsalam Umar; Mr. Aniete Sunday Williams and Mr. Femi Akolo to this work. 


\section{REFERENCES}

Abubakar M, Ayodele JT. Metal accumulation in trace sediment and in the shell of two species of freshwater molluscs in Tiga dam, Kano, Nigeria. Nig J Basic Appl Sci. 2002; 11: 81-90.

Adamu KB, Kori-Siakpere O. Effects of sublethal concentrations of Portland cement powder in solution on nitrogenous waste products of the African catfish, Clarias gariepinus (Burchell, 1822). Acta Zool Lit. 2008; 18 (1): 55-60.

Adelegan J. Environmental compliance, policy reform and industrial pollution in sub-Saharan Africa: Lessons from Nigeria. In: VIII International Conference on Linking Concepts to Actions: Successful Strategies for Environmental Compliance and Enforcements; Proceedings: Excerpt; 2008 April; Cape Town, South Africa: International Network for Environmental Compliance and Enforcement: 2008. p. 109-118.

Adeyemo OK. Haematological profile of Clarias gariepinus (Burchell, 1822) exposed to lead. Turkish J Fish Aquat Sci. 2007; 7: 163-9.

Akinsanya B, Otubanjo OA. Helminth parasites of Clarias gariepinus (Clariidae) in Lekki Lagoon, Lagos, Nigeria. Rev Biol Trop. 2006; 54 (1): 93-9.

Al-Attar AM. Biochemical effects of short-term cadmium exposure in the freshwater fish, Orechromis niloticus. $J$ Biol Sci. 2005; 5 (3): 260-5.

APHA. Standard method for the examination of water and waste water. $15^{\text {th }}$ ed. Washington DC: American Public Health Association; 1985. p. 413-426.

Atamanalp M, Kocaman EM, Ucar A, Alak G. The alterations in the haematological parameters of Brown trout Salmo trutta fairo, exposed to cobalt chloride. $J$ Anim Vet Adv. 2010; 9 (16): 2167-2170

Ayodele JT, Abubakar M. Chromium and copper in water sediments and their bioaccumulation by freshwater biovalves in Tiga Lake, Kano-Nigeria. J Environ Sci. 2001; 5 (1): 177-184

Borkovic SS, Pavloviae SZ, Kovacevic TB, Stajn AS, Paetroviae VM, Saieie ZS. Antioxidant defence enzymes activities in hepatopancreas, gills and muscles of spiny cheek crayfish Orconectes limosus) from the River Danube. Comp Biochem Physiol Part C Toxicol Pharmacol. 2008; 147: 122-8.

Biney C, Calamari D, Membe TW, Naeve H, Nyakageni B, Saad MAH. Scientific bases for pollution control in Africa inland waters. FAO Fisheries Report No. 369. Rome: FAO; 1987. p. 9-23.

Brungs WA, McCormick JH, Neiheisel TW, Spehar CE, Stokes GN. Effects of pollution on freshwater fishes. $J$. W. P. C. F. Washington DC. 1977: 49: 1425-1493.

Bruton MN. The survival of habitat desiccation by air breathing clariid catfishes. Environ Biol Fishes. 1979; 4: 273-280.

Choo PS, Williams MJ. Fisheries production in Asia: Its role in food security and nutrition. In: $9^{\text {th }}$ Asian Congress of Nutrition: Proceedings: Contributed paper; 2003 Feb; New Dehli, India: NAGA, WorldFish Centre Quarterly No. 26; 2003. p. 11-116.
Das MK. Studies on the effects of some pesticides and commonly used chemicals on Indian major carp and their ecosystem. (Ph. D Thesis). Bhubaneswas, India: Orissa University of Agriculture and Technology; 1998.

de Graaf G, Janssen J. Handbook on the artificial reproduction and pond rearing of the African catfish, Clarias gariepinus in sub-Saharan Africa: A handbook. Rome, Italy: FAO Fisheries Technical paper 362; 1996. p. 6.

Dhanekar S, Srivastava S, Rao KS, Pandya SS. Studies on toxic effects of least effective concentration of mercury in fish: A haematological study. Matsya, 1985; 11: 758.

Dunn JG. Clarias batrachus (Linaneus, 1958) A. K. A. walking catfish (USA) Mungur (India) Sat (Malaysia). Texas: University of Texas. Austin Ichthyology Zoo 334C; 2000. p. 6.

Eyo JE, Ezechie CV. The effects of rubber (Havea brasiliensis) seed meal based diets on diets acceptability and growth performance of Heterobranchus bidorsalis (male) x Clarias gariepinus (female) hybrid. J Sustain Trop Aquac Res . 2004; 10: 20-5.

Hendricks LJ. Erythrocyte counts and hemaglobin determinations for two species of suckers, genus Catostomus, from Colorado, Copeia, 1952; 4: 265-6.

Henry R, Canon DC, Winkelman JW. Clinical chemistry: Principles and techniques. Maryland, USA: Harper and Roe Publications; 1974. p. 543.

Hesser EF. Methods for routine fish haematology. Prog Fish Cult. 1960; 22: 104-171.

Hogendoorn H. Controlled propagation of Africa catfish, Clarias lazera $(\mathrm{C} \& \mathrm{~V}) .1$. Reproductive biology and field experiment. Aquaculture. 1979; 17 (4): 323-3.

Kaplan A, Ozabo LL, Ophem KE. Clinical chemistry: Interpretation and techniques. $3^{\text {rd }}$ ed. Philadelphia, USA: Lea and Febiger; 1988.

Kim SG, Park DK, Jang SW, Lee JS, Kim SS, Chung MH. Effects of dietary Benzo pyrene on growth and haematological parameters in juvenile rockfish, Sebastes schlegeli (Hilgendorf). Bull Environ Contam Toxicol. 2008; 81: 470-4.

King EJ, Armstrong AR. A convenient method for determining serum and bile phosphatase activity. Can Med Assoc J. 1934; 31: 376-381.

Kock G, Triendl M, Hofer R. Seasonal patterns of metal accumulation in Arctic char (Salvelinus alpines) from an oligotrophic Alphine Lake related to temperature. Can J Fish Aquat Sci. 1996; 53: 780-6.

Kori-Siakpere O, Ake JEG, Idoge E. Haematological characteristics of the African Snakehead, Parachanna obscura. Afri J Biotechnol. 2005; 4 (6): 527-530.

Kurtović B, Teskeredžić E, Teskerdžić Z. Histological comparism of spleen and kidney from farmed and wild European sea brass (Dicentrarchus labrax L.). Acta Adriat. 2008; 49 (2): 147-154.

Lind OT. A handbook of limnological methods. St. Louis, USA: C.V. Mosby Co.; 1979. p. 99.

Masheswaran R, Devapani A, Muralidharan S, Vehmurugan B, Ignacimuthu S. haematological studies of freshwater fish, Clarias batrachus (L.) exposed to mercury chloride. Int J Integ Biol. 2008; 2 (1): 49-54. 
Martinez CBR, Nagae MY, Zaia CTBV, Zaia DAM. Acute morphological and physiological effects of lead in the Neotropical fish, Prochilodus lineatus. Braz J Biol. 2004; 64 (4): 797-807.

Mohamed FAS. Bioaccumulation of selected metals and histopathological alterations in tissues of Oreochromis niloticus and Lates niloticus from Lake Nasser, Egypt. Glob Vet. 2008; 2 (4): 205-218.

Morgan JD, Iwana GK. Measurement of stressed states in the field. In: Iwana GK, Pickering AD, Sumpter JP, Schreck CB, editor. Fish stress and health in aquaculture, Society of Exploratory Biology Seminar Series No. 62; 1997. p. 247-268.

Musa SO, Omoregie E. Haematological changes in the mud fish, Clarias gariepinus (Burchell) exposed to malachite green. J Aquat Sci. 1999; 14: 37-42.

Nussey GJ, Van Vuren JHJ, Du Preez HH. Effects of copper on the haematology and osmoregulation of the Mozambicus tilapia, Oreochromis mossambicus (Cichlidae). Comp Biochem Physiol, 1995a; 111: 369380.

Ogundiran MA, Fawole OO, Adewoye SO, Ogundiran TA. Pathological lesions in the gills of Clarias gariepinus exposed to sublethal concentrations of soap and detergent effluents. J Cell Anim Biol . 2009; 3 (5): 78-82.

Okechi JK. Profitability assessment: A case study of African catfish (Clarias gariepinus) in the Lake Victoria Basin, Kenya. Final project. Fisheries Training Programme. Iceland: The United Nations University; 2004. p. 12.

Olaifa FE, Olaifa AK, Lewis OO. Toxic stress of lead on Clarias gariepinus (African catfish) fingerlings. Afri $J$ Biomed Res. 2003; 6: 101-104.

Ozmen M, Güngördü A, Kucukbay FZ, Gülar RE. Monitoring the effect of water pollution in Cyprinus carpio in Karakara Lake, Turkey. Ecotoxicol. 2006; 15: 157-169.

Palanivelu V, Vijayavel K, Ezhilarasilbalasubramanian S, Balasubramanian MP. Influence of insecticidal derivatives (Cartap Hydrochloride) from the marine polychaete on certain enzyme systems of the freshwater fish Orechromis mossambicus. J Environ Biol. 2005; 26: 191-196.

Peteri A, Nandi S, Chowdhury SN. Manual on seed production of African catfish (Clarias gariepinus). FAO document repository, BGD/87/045/92/22. Rome, Italy: FAO; 1992.

Platt WR. Color atlas and textbook of haematology. Philadelphia, USA: J. B. Lippncott Co,; 1969. p. 455.
Rahman, M.M., Varga, I. and Choudhury, S.N. (1992), Manual on African magur (Clarias gariepinus) culture in Bangladesh. Field document. Institutional strengthening in fisheries sector. [Cited 2007 Oct. 14]: Available from URL: http://www.fao.org/docrep/field/003/AC379E00.htm .

Sallie R, Tredger RS, Williams F. Drugs and the liver. Biopharm Drug Dispos. 1991; 12: 251-9.

Sani, U. Determination of some heavy metals concentrations in the tissues of tilapia and catfishes. Biokemistri. 2011: 23 (2): 73-80.

Seith N, Saxena KK. Haematological responses in a freshwater fish, Channa punctatus due to fenvalerate. Bull Environ Cont Toxicol. 2003; 71: 1192-9.

Schwartz MK, de Cediel N, Curnow DH, Fraser CG, Porter CJ, Worth HG, et al. International Federation of Clinical Chemistry, Education Committee and International Union of Pure and Applied Chemistry, Division of Clinical Chemistry: Definition of the terms certification, licensure and accreditation in clinical chemistry. J Clin Chem Clin Biochem. 1985; 23 (12): 899-901.

Shaw AFB. A direct method for counting the leucocytes, thrombocytes and erythrocytes of bird's blood. J Path Bact. 1930; 33 (2): 833-5.

Svensson B, Nilsson A, Jonsson E. Schutz A, Akesson B, Hagmar L. Fish consumption and exposure to persistent organochlorine compounds, mercury, selenium and methylamines among Swedish fishermen. Scand J Work Environ Health. 1995; 21: 96-105.

Tietz NW. Clinical guide to laboratory tests. $2^{\text {nd }}$ ed. Philadelphia, USA: W. B. Saunders Company; 1990. p. 554-6.

Van der Merve MVD, Van Vuren JHJ, Du Preez HH. Lethal copper concentration levels for Clarias gariepinus (Burchell, 1822): A preliminary study. Koedoe. 1993; 36 (2): 77-86.

Van Vuren JHJ. The effects of toxicants on the haematology of Labeo umbratus (Teleostei: Cyprinidae). Comp Biochem Physiol. 1986; 93: 155159.

Viveen WJAR, Rither CJJ, van Oordt PGJ, Janssen JAL, Huisman EA. Practical manual for the culture of the African catfish (Clarias gariepinus). The Hague, Netherlands: Directorate General for International Technical Cooperation; 1985. p. 93.

Weckler P. Information resources in toxicology. $3^{\text {rd }}$ ed. San Diego: Academic Press; 2000. p. 278.

Wilson RW, Taylor EW. The physiological responses of freshwater rainbow trout, Onchorynchus mykiss, during acute exposure. J Comp Physiol. 1993; 163b: 36-47. 